Pre-print version of: PACTE. Building a translation competence model. In: Alves, Fabio (ed.). Triangulating translation: perspectives in process oriented research. Amsterdam: John Benjamins, 2003, p. 43-66. ISBN 9789027216519. DOI: $\underline{10.1075 / \mathrm{btl} .45}$ 


\title{
Building a Translation Competence Model
}

\author{
PACTE GROUP \\ A. Beeby, M. Fernández Rodríguez, O. Fox, A. Hurtado Albir, \\ W. Neunzig, M. Orozco, M. Presas, P. Rodríguez Inés, L. Romero \\ (Principal investigator: Amparo Hurtado Albir) \\ Universitat Autónoma de Barcelona
}

\begin{abstract}
This chapter presents the translation competence model that is being worked on by the PACTE group and that is the basis for designing the hypotheses of an empirical-experimental study of translation competence. This research is the first stage in a larger project to investigate the process of translation competence acquisition. The first part of the chapter describes our theoretical framework and the first models that we designed in 1998. This is followed by a brief presentation of the design of the research project. The last part of the chapter deals with the modification we have introduced in our 1998 translation competence model as a result of the first exploratory studies.
\end{abstract}

\section{Introduction}

The PACTE research group (Process in the Acquisition of Translation Competence and Evaluation) was formed in October 1997 to investigate the Acquisition of Translation Competence in written translation into and out of the foreign language (inverse and direct translation). All the founding members of the group are translators and translation teachers who train professional translators in the Facultat de Traducció i d'Interpretació of the Universitat Autònoma de Barcelona. Our language combinations include English, French and German $\leftrightarrow$ Spanish and Catalan. We cover both direct and inverse translation directions. This means that we all have different theoretical and methodological backgrounds, but for a long time we had all felt the need for more information about how trainee translators learn to translate in order to create better teaching programmes, improve evaluation methods and unify pedagogical criteria. Therefore, in 1997, we decided to form a research group. Our first objective was to unify criteria, so our first task was to build a model of the characteristics that define the professional translator (translation competence) and a model of how translation competence is acquired (translation competence acquisition) that could be validated empirically. We also had to decide on an appropriate research design. 
We started from the concept of translation as a communicative activity directed towards achieving aims ${ }^{1}$ that involves taking decisions and solving problems ${ }^{2}$, and requires expert knowledge, like any other activity with these characteristics. In Translation Studies, this expert knowledge is called Translation Competence. Consequently, the first stage in our research project is an empirical study of how written translation competence functions, as there is no generally accepted translation competence model that has been validated empirically.

In our research, translation competence is being studied from two complementary points of view: (1) the translation process, through the collection and analysis of data obtained from experimental studies of the mental processes used to translate, and the competencies and abilities required; (2) the translation product, through the collection and analysis of data obtained from an electronic corpus consisting of the texts translated by the subjects participating in the experiment. Different instruments and different types of data-collecting methods are being used, both qualitative and quantitative methods, so that the data can be collated and triangulated.

There are two main stages in our research project: (Stage 1) an empirical study of translation competence; (Stage 2) an empirical study of translation competence acquisition.

This chapter centres on the translation competence model on which our research is based.

\section{Theoretical Framework and Models}

In 1998, PACTE developed a first version of a holistic model for Translation Competence and a dynamic model for the Acquisition of Translation Competence (PACTE 1998, 2000, 2001; Hurtado Albir 1999, 2001: 375-408). Our theoretical and working hypotheses are based on these models.

Theoretical framework

These models were constructed taking into account: (1) existing work in other disciplines that have defined notions related to translation competence acquisition; (2) models proposed to define translation competence and the translation competence acquisition; (3) empirical research on written translation.

1.Research into notions, such as "competence", "expert knowledge" and "learning processes" in other disciplines (e.g. Pedagogy, Psychology and Language Teaching).

Given that we consider translation to be an act of communication, we have drawn on studies of communicative competence ${ }^{3}$. These studies stress 
the difference between competence (defined as a system of underlying knowledge and abilities) and the activation of this competence under certain psychological and contextual conditions. Furthermore, these studies consider that this competence is made up of a set of inter-related sub-competencies, amongst which are those needed to language use. Fundamental importance is given to the strategic component to plan, repair, evaluate and carry out the process. Some authors (e.g. Bachman 1990) also include psychophysiological mechanisms, that is the psychological and neurological processes implied in the real use of language.

However, translation competence, that is the professional translator's competence, differs from communicative competence in that it is expert knowledge. The characteristics of expert knowledge and its acquisition have been studied in psychology, cognitive psychology, pedagogy, etc. ${ }^{4}$. Expert knowledge is defined as being categorical or abstract and having a wide knowledge base; it is conscious and can be made explicit; it is organised in complex structures and can be applied to problem solving.

An essential element in understanding how expert knowledge works and is acquired, is the distinction between declarative and procedural (or operative) knowledge made by Anderson (1983) $)^{5}$. On the one hand, declarative knowledge consists of knowing what: it is easily verbalised; it is acquired by being exposed to information and its use is normally controlled (e.g., knowing the addresses of web pages that are useful for translator documentation). On the other hand, procedural knowledge consists of knowing how: it is difficult to verbalise; it is acquired through practice and its use is mainly automatic (e.g., knowing how to use a web page to guarantee a translation's precision and economy). The procedures with which this knowledge is acquired or built (strategies and techniques) are very important.

The acquisition of expert knowledge passes through different stages. Beginning with the initial stage (novice knowledge), the knowledge gradually becomes more automatic until the final stage (expert knowledge) is reached. This acquisition can be natural or guided, through teaching, but in both cases there is a learning process. Studies of learning processes stress that the acquisition of any knowledge is a dynamic process, cyclical rather than lineal in nature. The process includes successive stages of restructuring knowledge in which learning strategies play an essential role (i.e., the operations used by the learner to obtain, store, recover and use information).

2.Models used to define "translation competence" and the "acquisition of translation competence".

Unlike other disciplines in which numerous studies have been carried out to determine what constitutes expert knowledge in the field and how this knowledge is acquired, no generally accepted model of what constitutes translation competence or the acquisition of translation competence exists in 
the field of Translation Studies. Some proposals have been made with respect to translation competence in written translation ${ }^{6}$. Most, however, are limited in scope as they deal only with specific aspects of translation competence. All the proposals coincide in describing translation competence as a set of components (in addition to strictly linguistic knowledge): cultural and subject knowledge, documentation and transfer ability, etc. Nevertheless, only a few include the strategic component ${ }^{7}$ and none mention the psycho-physiological component $^{8}$. On the other hand, most of proposals are simply lists of characteristics that define the translator, and do not suggest how these components are related to each other or if there are hierarchies amongst them. Furthermore, none have been validated empirically, i.e. data was not collected and analysed within the framework of a structured research project.

As far as we know, only two studies have attempted an empirical approach to research into translation competence as a whole: Lowe (1987) and Stansfield, Scott and Kenyon (1992). However, as Orozco (2000: 113ff) points out, Lowe's study is, in fact, a proposal of the elements that indicate levels of translation competence, not an empirical study. According to Orozco, the work of Stansfield, Scott and Kenyon (1992), is the only real empirical-experimental study of translation competence. The instrument they created, called Spanish into English Verbatim Translation Exam (SEVTE), was validated by reliability and validity tests. However, the authors themselves indicate that the results cannot be generalised, given the limitations of the sample (7 FBI employees).

As far as the acquisition of translation competence is concerned, very few proposals have been made ${ }^{9}$. On the other hand, although some empirical studies have been carried out to compare the performance of professional translators and that of students of translation ${ }^{10}$, no longitudinal study has yet been carried out to monitor the acquisition of translation competence as a whole.

\section{Empirical research on written translation in Translation Studies.}

Empirical research into written translation first began in the $1980 \mathrm{~s}^{11}$. Although these studies do not focus on translation competence as a whole, some of them approach partial aspects that cast light on some of the elements that make up translation competence. For example, there have been studies of the translator's linguistic knowledge (Mondhal and Jensen 1992), linguistic and extra-linguistic knowledge (Tirkkonen-Condit 1992, Dancette 1995, Alves 1996), extra-linguistic knowledge (Dancette 1994, 1997); abilities and aptitudes, such as creativity, emotional qualities and attention-span (Kussmaul 1991, 1995, 1997; Tirkkonen-Condit and Laukkanen 1996); documentation (Atkins and Varantola 1997, Livbjerg and Mees 1999); strategies (Krings 1986, Lörscher 1991, 1992, 1993, Kiraly 1995). 
The 1998 model of Translation Competence: A Holistic Model

The translation competence models that have been proposed in Translation Studies are not firmly based on validated empirical research that provide the data needed to describe the components of translation competence and the connections between the components. Therefore, the PACTE group's first objective is to provide this research.

Our 1998 holistic model of translation competence (see PACTE 2000) drew on the contributions mentioned above. A distinction is made between competence (the underlying system of knowledge) and performance (translating). It is postulated that translation competence is qualitatively different from bilingual competence, the latter being one of the several components that make up translation competence and that these components are inter-related and there are hierarchies amongst them.

Furthermore, translation competence is considered to be expert knowledge and it is primarily procedural knowledge, where strategies play a very important role and most processes are automatic. Consequently, and taking into account the results of the empirical studies in written translation mentioned above, two components were added to the model: the strategic and the psycho-physiological.

Thus, the basic premises of the model were:

(1) Translation competence is qualitatively different from bilingual competence;

(2) Translation competence is the underlying system of knowledge needed to translate;

(3) Translation competence is an expert knowledge and, like all expert knowledge, comprises declarative and procedural knowledge; the latter is predominant;

(4) Translation competence is made up of a system of sub-competencies that are inter-related, hierarchical and that these relationships are subject to variations.

(5) The sub-competencies of translation competence are considered to be: a language sub-competence in two languages; an extra-linguistic subcompetence; an instrumental/professional sub-competence; a psychophysiological sub-competence; a transfer sub-competence; and a strategic sub-competence.

The language sub-competence was defined as the underlying system of knowledge and abilities necessary for linguistic communication in both languages. The extra-linguistic sub-competence was defined as implicit or explicit knowledge about the world in general and specific areas of knowledge: knowledge about translation (its ruling premises: types of translation unit, the processes required, etc); bicultural knowledge; encyclopaedic knowledge and subject knowledge (in specific areas). The instrumental/professional sub-competence was defined as the knowledge and 
abilities associated with the practice of professional translation: knowledge and use of all kinds of documentation sources; knowledge and use of new technologies; knowledge of the work market and the profession (prices, types of briefs, etc.). The psycho-physiological sub-competence was defined as the ability to use psychomotor, cognitive and attitudinal resources

In this model, the transfer sub-competence was the central competence that integrates all the others. It was defined as the ability to complete the transfer process from the source text to the target text, that is, to understand the source text and re-express it in the target language, taking into account the purpose of the translation and the characteristics of the receptor.

The strategic sub-competence included all the individual procedures, conscious and unconscious, verbal and non-verbal, used to solve the problems encountered during the translation process. This sub-competence plays an essential role in relation to all the others, because it is used to detect problems, take decisions, and make up for errors or weaknesses in the other subcompetencies.

All these sub-competencies interact to make up translation competence and they are integrated in every translation act, establishing inter-relations, hierarchies and variations. The inter-relations are controlled by the strategic sub-competence, because its role is to monitor and compensate for the other sub-competencies, as it makes up for weaknesses and solves problems. In the 1998 model we considered that transfer competence plays a central role in the hierarchy and integrates the other sub-competencies.

Variations in translation competence occur in relation to: directionality (direct or inverse translation); language combinations; specialisation (technical, legal, literary, etc.); the translator's experience or the translation context (translation brief, time available, etc.). Thus, for example, in inverse translation the instrumental/professional sub-competence gains importance; the strategies used by the translator vary according to the distance between the language pairs used in the translation; in each translation speciality greater importance will be given to different psychological abilities (logical reasoning in technical translation, creativity in literary translation); a greater degree of automation may be expected when the translator is very experienced; the translation context (translation brief, time, etc.) may require a certain subcompetence to be activated (instrumental/professional, psycho-physiological, etc.).

\section{A Dynamic Model of Translation Competence Acquisition}

If few studies of translation competence exist, there are even fewer of translation competence acquisition. There are some relevant studies in other disciplines, but existing translation studies are only based on observation and experience, and there are no empirical-experimental studies based on representative samples. Although there are a few empirical studies that have 
compared students' performance with that of the professional translator (Jääskeläinen 1987, 1989; Tirkkonen-Condit 1990; Jääskeläinen and Tirkkonen-Condit 1991; Seguinot 1991, etc.), no study has been made of the process of translation competence acquisition as a whole. As stated above, PACTE's final aim is empirical-experimental research into translation competence acquisition.

The PACTE model developed in 1998 (see PACTE 2000) includes insights from research into the learning process and postulates that translation competence acquisition is a process of restructuring and developing subcompetencies of translation competence. Therefore, translation competence acquisition is defined as:

(1) A dynamic, spiral process that, like all learning processes, evolves from novice knowledge (pre-translation competence) to expert knowledge (translation competence); it requires learning competence (learning strategies) and during the process both declarative and procedural types of knowledge are integrated, developed and restructured.

(2) A process in which the development of procedural knowledge and, consequently, of the strategic sub-competence are essential.

(3) A process in which the translation competence sub-competencies are developed and restructured.

In the process of acquiring sub-competencies there are also relations, hierarchies and variations. Thus, in the acquisition of translation competence, the sub-competencies: (1) are inter-related and compensate for each other; (2) do not always develop in parallel; (3) are organised hierarchically; (4) variations occur in relation to translation direction, language combinations, specialisation and the learning context. Therefore, the translation competence acquisition process may not be parallel for direct and inverse translation. Furthermore, depending on the language combinations, the process may be more or less rapid, or, depending on the translation speciality (legal, literary translation, etc.) one sub-competence may be more important than another. On the other hand, the learning context (formal training, self-learning, etc.) influences the acquisition process, as does the methodology used by teachers.

\section{Research Design}

Our research design includes several different types of tests with different groups of subjects (PACTE 2001, 2002a, 2002b; Beeby 2000). Six language pairs are used: English-Spanish; German-Spanish; French-Spanish; EnglishCatalan; German-Catalan; French-Catalan.

There are several reasons for choosing these combinations:

(1) We want to experiment with several language combinations to observe whether translation competence functions in the same way in them all. 
Above all, we are interested in comparing language combinations where the languages are close to each other (French-Spanish; FrenchCatalan) with other combinations where the languages are more distant (English-Spanish; German-Spanish; English-Catalan; GermanCatalan).

(2) These six combinations are the most common in the professional translation market in Catalunya; the inclusion of two A languages (Spanish and Catalan) reflects the bilingual, bicultural reality of Catalunya.

(3) English, French and German are the three B languages taught in our Faculty and they are used in translation classes in both directions (direct and inverse).

Subjects, instruments and experimental tasks

Two types of subjects are used to study translation competence: professional translators (experimental group 1) and "bilingual" subjects who do not translate (experimental group 2). A questionnaire prepared for each group is used to form homogeneous, representative groups and exclude subjects that might introduce extraneous variables. This is to guarantee that the experimental subjects really belong to the samples that are the object of study (professional translators and bilingual subjects). For the groups to be comparable, certain features or characteristics that could distort the results have to be controlled (e.g., age, specialisation, length of work experience).

Three types of tests are carried out: exploratory studies, pilot tests and experiments. The exploratory studies are observational and their purpose is to improve the instruments and the hypotheses. The purpose of the pilot tests is to test the improved instruments. Both are used to prepare the experiment.

Several different instruments have been designed: a commercial software programme (PROXY), protocol texts for translation into and out of the foreign language, questionnaires, a direct observation chart to observe subjects' activities while translating, and retrospective and guided Think-Aloud-Protocols (TAPs). Simultaneous TAPs are not used, not only because they make the situation very artificial, but also because they may change the process, as the TRAP group in Copenhagen suggests: "One of the problems in relation to TAP's is whether it is possible to engage in two complicated actions of a similar nature (namely translating and thinking aloud) simultaneously, and whether one influences the other. Having to think aloud during the translation process may change the process, which obviously affects the quality of the data." (Hansen et al, 1998:62)

PROXY is a user monitoring programme, i.e. a programme that permits the remote control of workstations and users connected to the same network, that is able to record and monitor subjects' activities during the translation process, in real time ${ }^{12}$. The use of PROXY is most useful in our 
study, particularly in relation to ecological validity (i.e., to guarantee that the experiment reflects the real situation) ${ }^{13}$. The advantages its offers are as follows: (1) it is compatible with Microsoft Windows, so that subjects can work with the text processor they are most familiar with; (2) it can be used in conjunction with other Windows applications, so that subjects can carry out information searches on the Internet or in on-line dictionaries and CD-Roms; (3) all subjects' activities may be viewed and recorded in real time and viewed later at different speeds (as if it were a video recording); (4) all subjects' activities during the translation process can be recorded and the data obtained cross-referenced with data collected using other instruments (direct observation charts, questionnaires, TAPs, etc.); (5) subjects are unaware of the fact that their activities are being monitored and recorded.

Protocol texts have been selected for subjects to translate, one into and one out of the foreign language. The texts included indicators of all the translation competence sub-competencies, except for the strategic and transfer sub-competencies. These two cannot be observed directly in the texts, but only during the experimental tasks through direct observation and recording by PROXY. Therefore, following our translation competence model, the texts include indicators of: language problems (lexical, grammatical and textual); extra-linguistic problems (encyclopaedic, cultural, subject-matter); instrumental/professional problems (related to the translation brief, documentation difficulties related to the number of queries or the unusual nature of the information search); psycho-physiological problems (related to coherence, style, etc., where creativity, logical reasoning, etc., have to be activated to produce functional and dynamic equivalencies).

Different types of questionnaires are used. The first, (Questionnaire I), is designed to obtain information about the subjects (translation training, professional experience, type of texts translated, etc.) and their concept of translation. The second, (Questionnaire II), is used to obtain information from the subjects about the protocol texts they have translated (the problems encountered and the strategies used to solve them).

The experimental tasks are the same for all the tests and consist of:

(1) the completion of a questionnaire to obtain information about the subject (Questionnaire I);

(2) the translation of two texts, one into and one out of the foreign language, monitored and recorded by PROXY;

(3) the completion of a questionnaire (Questionnaire II) after translating each of the two texts;

(4) the completion of a retrospective, guided TAP; whilst viewing the recording of the subject's translation on the screen the researcher tries to recover as much information as possible from the translator about his/her cognitive behaviour and asks for clarification when necessary (the reasons for certain decisions, pauses, corrections, etc.). 
As the subjects translate each text, any activities that cannot be recorded by PROXY are observed, without the subject realising, and recorded in observation charts (consultation of printed materials, reading of the source or target texts, etc.). The target texts produced by the subjects will be used to build an electronic corpus of texts and this information will be crossreferenced with the data gathered from the experiment.

In the study of translation competence acquisition, the experimental subjects are translation students and the group of professional translators acts as the reference group. The same types of tests are carried out over a period of two years, starting with translation students at the beginning of their training, and using the same experimental tasks and instruments as described above, using a repeated measurement experiment design.

Current Stage of Research: Exploratory Studies in Translation Competence.

The conceptual stage of our study has been completed with the construction of a holistic model of Translation Competence and a dynamic model of Translation Competence Acquisition, which were used to deduce theoretical and working hypotheses. Furthermore, the methodological stage has been initiated by designing the research, measuring instruments and experimental tasks.

Our research is now focused on the empirical study of translation competence. In preparation for the final experiment, two exploratory tests were carried out during the year 2000. In the first, subjects were members of the PACTE research group. In the second, subjects were six professional translators working in three language combinations (English-Spanish; German-Spanish; French-Spanish), each language combination was represented by two translators. In both exploratory tests, instruments and experimental tasks designed for use in the final experiment were used.

These exploratory tests were observational and the aims were ${ }^{14}:$ (1) to test the holistic model of translation competence developed in 1998 (the subcompetencies involved and the relationship between each); (2) to test and improve the measuring instruments and the experimental tasks to be used in the final experiment; (3) to establish our empirical hypotheses; (4) to select variables. The results obtained from these tests are currently being analysed and our findings to date are now being used to improve our measuring instruments and our model of translation competence.

Findings obtained from the different instruments used in these tests were collated and cross-referenced using custom-designed charts. Although an exhaustive analysis has yet to be made of the results obtained, it has become clear to the Group that certain changes must be made in the measuring instruments used, and the 1998 model of translation competence should be revised $^{15}$. 
Our tests have confirmed that the software program PROXY is a particularly useful instrument for observing the translation process, and the experimental tasks designed by the Group are appropriate for studying the cognitive dimensions of translation competence. Although more detailed analysis is required, it would appear that some improvements are, nevertheless, required in the measuring instruments developed in relation to the texts used, the indicators of sub-competencies and the questionnaires. Given that this article focuses on the most important issues that have led us to question the 1998 model of translation competence, the modifications made to the instruments are not included (see PACTE 2002a).

\section{Outcome of the exploratory test in Translation Competence}

Our exploratory tests have enabled us to observe, and more precisely define, a much wider range of activities carried out by subjects during the translation process and have shown the need to modify our 1998 translation competence model.

The Expert Translator's Observable Activities.

One of the most significant results of the exploratory tests is a catalogue of activities based on observation of the translator at work. These activities were detected through direct observation (using the direct observation chart) and through viewing the PROXY recordings (see Table 1):

(1) Activities detected through direct observation: first-time reading of the source text (before writing), re-reading of the source text, revising the target text, underlining, making notes, comparing source text and target text and consultation of printed materials.

(2) Activities detected through viewing the PROXY recordings: immediate solution to a translation problem; non-immediate solution to a translation problem (after a pause, consultation, etc.); pause (longer than 5 seconds); postponed solution; solution of a postponed solution; temporary solution; final solution of a temporary solution; on-line consultation; use of new technologies (Internet, text processing); and corrections (lexical items, grammar, cohesion, coherence, etc.).

In order to investigate these activities we need to measure in the experiment: (1) the time spent on each activity, to know which activities take up most time in the expert translation process; (2) the number of times each activity takes place, to know which are most commonly used by the expert translator; (3) the moment they take place in the translation process, so as to be able to follow the development of the process (movements backwards and forwards in the text). Furthermore, we need to describe the characteristics of these activities: Which elements are underlined and marked? What happens in the 
pauses? What are the steps taken to reach a not immediate solution? What happens between a postponed solution and its solution? What happens between a provisional solution and its solution? What kinds of corrections are carried out? Finally, we have to relate these activities to the translation competence sub-competencies.

Table 1. Catalogue of the expert translator's observable activities.

\begin{tabular}{|l|l|}
\hline DIRECT OBSERVATION & RECORDED IN PROXY \\
\hline First reading of the source text & Immediate solution \\
Re-reading of the source text & Not immediate solution \\
Revising the target text & Pause (longer than 5 seconds) \\
Underlining & Postponed solution \\
Making notes & Solution of a postponed solution \\
Comparing source text and target text & Provisional solution \\
Consultation of printed material & Solution of a provisional solution \\
& Text processing \\
& Consultation of electronic material \\
& Corrections \\
\hline
\end{tabular}

Several characteristics of these activities indicate the complexity of the expert translator's behaviour, which is something we should study in our experiment.

\section{Observable and Non-observable Behaviour}

The activities detected in the expert translator's behaviour are observable activities. However, translation competence as a whole is a construct that cannot be observed directly. We can observe behaviour (the catalogued activities), but not complex mental operations, which can only be accessed indirectly through the activities.

Therefore, the catalogued activities are the translator's directly observable behaviour, the result of cognitive procedures that cannot be observed directly. Nevertheless, we can access them indirectly using different instruments ${ }^{16}$. Thus, the TAP and the questionnaires should help us to collect information about this cognitive behaviour that cannot be observed by direct observation or the PROXY recordings. 


\section{Automatic Activities}

We have observed that these activities may occur immediately (automatically) or not immediately (requiring more time and intermediate stages). Our hypothesis is that the expert translator takes more immediate decisions that lead to a positive outcome than the trainee translator, because the expert translator already possesses expert knowledge and this, like all expert knowledge, is largely automatic. Thus, in the experiment, attention should be paid to immediate positive solutions of an element in the source text, which should be more frequent amongst expert translators than trainee translators.

The questionnaires and the retrospective guided TAP that will be used in the experiment should provide information about how conscious the translator is about these more automatic activities and show that the translator is not always conscious of this type of cognitive procedure.

\section{Problem Solving and Decision Making}

Interruptions in the process (pause) and elements that cause the translator to delay taking a decision (postponed solution) or to take a provisional decision (provisional solution) are the best indicators of the existence of a problem for the translator. They mark the activation of sub-competencies and the application of strategies (consultation of documentary sources, reconsideration of the context, mnemonic aids, etc.) that help the translator to take decisions. The translator takes decisions that affect the translation at all levels: global aspects (work plan, etc.); macro-structural elements (corrections that affect the coherence of the target text); micro-structural elements (corrections related to micro-units of translation: lexical, grammatical, etc.). All these questions will have to be observed in detail in the experiment.

\section{Combinations and Chains of Activities}

We have observed that when solving a translation problem, the translator combines activities, and links together several activities, depending on the particular problem. This indicates the crucial role of the strategic subcompetence in controlling the whole process. Thus, in the experiment, we will have to observe how these activities are combined and the hierarchical relationships amongst them.

\section{The need to redefine the 1998 Translation Competence Model}

When attempting to establish links between subjects' activities and specific translation competencies, as a first step towards defining our empirical hypotheses (i.e. what we wish to observe and contrast in our experiment), and looking for ways to measure each sub-competence, we have found it necessary to revise the definition and functions of each of the translation subcompetencies included in our 1998 model of Translation Competence. 
The modifications now being considered are related above all to the following points.

(1) It would seem that the transfer sub-competence is not just one subcompetence of the whole group of sub-competencies that make up translation competence. All bilinguals possess a rudimentary transfer ability, the natural translation ability described by Harris and Sherwood (1978). The differences between this ability and expert translation competence is due to the interaction amongst the other sub-competencies, and in particular, to the role played by the strategic sub-competence. Therefore, it would seem that this special transfer capacity of the expert translator is the combination of all the sub-competencies, i.e. translation competence: the ability to carry out the transfer process from the source text to the production of the target text in function of the receptor's needs and the purpose of the translation. This redefinition of transfer competence obliges us to modify the characteristics of the linguistic and the strategic sub-competencies.

(2) Thus, there are two important aspects to be considered in relation to the linguistic sub-competence: the fact that the expert translator as a bilingual has the ability to change from one language to another, but also, that the translator is able to separate the two languages that are in contact.

(3) It is becoming increasingly clear that strategic sub-competence plays a crucial role in translation competence since it is used to: plan the translation project; activate, monitor and compensate for shortcomings in other translation sub-competencies; detect translation problems; apply translation strategies; monitor and evaluate both the translation process and the partial results obtained in relation to the intended target text, etc.

(4) Given its importance within translation competence, knowledge about translation, which had previously been ascribed to extra-linguistic subcompetence and instrumental/professional sub-competence, would now appear to constitute a specific sub-competence Data collection would be facilitated.

(5) Finally, psycho-physiological sub-competence would appear to warrant a status somewhat different from that of other sub-competencies since it forms an integral part of all expert knowledge. Rather than 'subcompetence' it would perhaps be more appropriate to speak of psychophysiological 'components'.

On the other hand, we have realised that if translation competence is expert knowledge, then it should be defined in terms of declarative and procedural knowledge.

Redefinition of the holistic translation competence model 
As a result of the above considerations, we have adjusted our definition of translation competence and its sub-competencies as follows.

Translation competence is the underlying system of knowledge needed to translate. It includes declarative and procedural knowledge, but the procedural knowledge is predominant. It consists of the ability to carry out the transfer process from the comprehension of the source text to the reexpression of the target text, taking into account the purpose of the translation and the characteristics of the target text readers. It is made up of five subcompetencies (bilingual, extra-linguistic, knowledge about translation, instrumental and strategic) and it activates a series of psycho-physiological mechanisms.

The bilingual sub-competence. Predominantly procedural knowledge needed to communicate in two languages. It includes the specific feature of interference control when alternating between the two languages. It is made up of pragmatic, socio-linguistic, textual, grammatical and lexical knowledge in the two languages.

Pragmatic knowledge is knowledge of the pragmatic conventions needed to carry out language acts that are acceptable in a given context; they make it possible to use language to express and understand linguistic functions and speech acts. Socio-linguistic knowledge is knowledge of the socio-linguistic conventions needed to carry out language acts that are acceptable in a given context; this includes knowledge of language registers (variations according to field, mode and tenor) and of dialects (variations according to geographical, social and temporal dialects). Textual knowledge is knowledge of texture (coherence and cohesion mechanisms) and of different genres with their respective conventions (structure, language features, etc.). Grammatical-lexical knowledge is knowledge of vocabulary, morphology, syntax and phonology/graphology.

Extra-linguistic sub-competence. Predominantly declarative knowledge, both implicit and explicit, about the world in general and special areas. It includes: (1) bicultural knowledge (about the source and target cultures); (2) encyclopaedic knowledge (about the world in general); (3) subject knowledge (in special areas).

Knowledge about translation sub-competence. Predominantly declarative knowledge, both implicit and explicit, about what translation is and aspects of the profession. It includes: (1) knowledge about how translation functions: types of translation units, processes required, methods and procedures used (strategies and techniques), and types of problems; (2) knowledge related to professional translation practice: knowledge of the work market (different types of briefs, clients and audiences, etc.) ${ }^{17}$. 
Instrumental sub-competence. Predominantly procedural knowledge related to the use of documentation sources and an information and communication technologies applied to translation: dictionaries of all kinds, encyclopaedias, grammars, style books, parallel texts, electronic corpora, searchers, etc.

Strategic sub-competence. Procedural knowledge to guarantee the efficiency of the translation process and solve the problems encountered. This is an essential sub-competence that affects all the others and causes inter-relations amongst them because it controls the translation process. Its functions are: (1) to plan the process and carry out the translation project (choice of the most adequate method); (2) to evaluate the process and the partial results obtained in relation to the final purpose; (3) to activate the different sub-competencies and compensate for deficiencies in them; (4) to identify translation problems and apply procedures to solve them.

Psycho-physiological components. Different types of cognitive and attitudinal components and psycho-motor mechanisms. They include: (1) cognitive components such as memory, perception, attention and emotion; (2) attitudinal aspects such as intellectual curiosity, perseverance, rigour, critical spirit, knowledge of and confidence in one's own abilities, the ability to measure one's own abilities, motivation, etc.; (3) abilities such as creativity, logical reasoning, analysis and synthesis, etc.

These considerations are illustrated in the following figure:

Table 2. Model of Translation Competence Revisited 


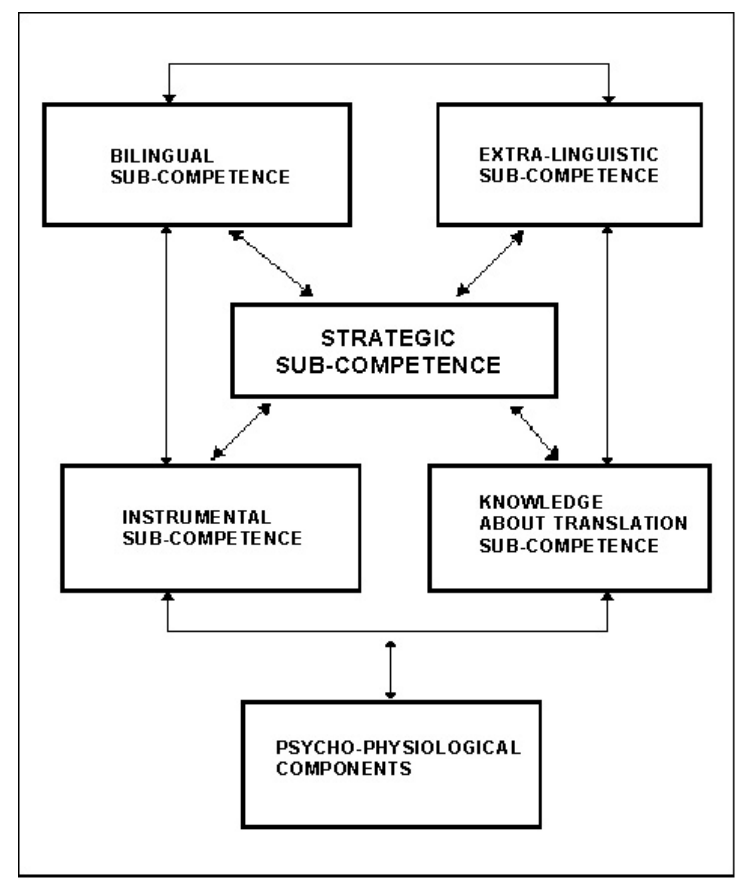

\section{Conclusion}

The experience gained from the research carried out so far has led us to redefine the sub-competencies of the 1998 translation competence model and adjust their functions. It has become clear that translation competence is qualitatively different from bilingual competence and that it is expert knowledge in which procedural knowledge is predominant. Furthermore, it has become increasingly clear that translation competence is made up of a set of sub-competencies that are inter-related and hierarchic, with the strategic sub-competence occupying a dominant position.

Once we have concluded the analysis of the data obtained from our exploratory tests, the next stage of our research will be to redefine our theoretical and working hypotheses (see PACTE 2001), establish our empirical hypotheses and select the variables to be observed in our final experiment.

Obviously, the revised model presented here is still subject to modifications, because the definition of our hypotheses may lead to the need for certain adjustments. Only when we have completed the experiment will we have the necessary data to validate the model and reach a final version.

Although ours is an extended research project, and not without its difficulties, we believe an attempt must be made to investigate the acquisition of translation competence empirically. We are convinced that knowing more about how translation competence functions and how it is acquired will lead 
to better curricular designs for training professional translators. This is our final goal.

\section{Notes}

1 See, for example, Nord (1997).

2 See, for example, Wilss $(1988,1996)$.

3 For our model, the most relevant studies of communicative competence are those by Hymes (1971), Canale and Swain (1980), Canale (1983), Widdowson (1989), Spolsky (1989), Bachman (1990), etc.

4 Also important are the studies of expert knowledge and learning processes by Ryle (1949), Anderson (1983), Dreyfus and Dreyfus (1986), Lesgold and Glaser (1989), Pozo and Postigo (1993), Pozo (1996), Ellis (1997), Puente Ferreras (1998), etc.

5 This distinction is based on the difference established by Ryle (1949) between knowing what and knowing how, i.e. the procedures by which this knowledge is acquired.

6 Proposals related to the functioning of translation competence were made by authors such as Lowe (1987), Bell (1991), Hewson y Martin (1991), Nord (1992), Pym (1992), Presas (1996), Hurtado Albir (1996a, 1996b), Beeby (1996), Hansen (1997), Hatim and Mason (1997), etc. Other proposals made after the beginning of the PACTE project are: Risku (1998), Campbell (1998), Neubert (2000), Kelly (2002), etc.

7 See. Hurtado (1996b), Hansen (1997), etc.

8 This is only included in Kelly (2002).

9 Proposals related to the acquisition of translation competence include those by Harris (1973, 1977, 1980), Harris and Sherwood (1978), Toury (1995), Shreve (1997) and Chesterman (1997).

10 See, for example, Jääskeläinen (1987, 1989), Tirkkonen-Condit (1990), Jääskeläinen and Tirkkonen-Condit (1991), Kiraly (1995), Lorenzo (1999), etc. Seguinot (1991) is an interesting longitudinal study of the translation strategies used by students, based on the results of translation tests given over a period of six years, at the beginning and end of their training.

11 For a review of empirical-experimental research in translation, see Orozco 2000: 48-49 and Orozco 2001.

12 The use of PROXY for research in translation was proposed by W. Neunzig and presented in his doctoral thesis (Neunzig 2001).

13 The criteria of ecological validity, as defined in the philosophy of science, postulate that all experiments should reflect a real situation, and avoid artificiality. It is perhaps one of the most difficult problems in any laboratory experiment. It is obvious that our type of research is by definition "artificial", because it is difficult to design a situation in which the subjects, e.g., the translators, are not influenced by the context or by the mere fact that they 
know they are participating in an experiment. We do not use the aforementioned think aloud protocols and video recordings to collect data because they lack ecological validity.

14 See PACTE 2003 for a detailed description of the instruments and experimental tasks.

15 These findings were presented in the II Encontro Internacional de Tradutores (Belo Horizonte, 23-27 July, 2001) and in the Third International EST Congress (Copenhagen, 30 August-1 September, 2001).

16 See, for example, in this volume, the work of Alves and Gonçalves; Hansen; Livbjerg and Mees, that shed light on the translator's cognitive processes, using TAPs, the Translog software, etc.

17 Other aspects intervene, such as: knowledge of translation associations, tarifs, taxes, etc.

\section{References}

Alves, F. 1996. "Veio-me um 'click' na cabeça: The Theoretical Foundations and the Design of a Psicholinguistically Oriented, Empirical Investigation on German-Portuguese Translation Processes", Meta 41(1): 33-44.

Anderson, J.R. 1983. The architecture of cognition, Cambridge: Harvard University Press.

Atkins, B.T.S, and Varantola K. 1997. "Monitoring Dictionary Use", International Journal of Lexicography 10/(1): 1-145.

Bachman, L.F. 1990. Fundamental Considerations in language Testing, Oxford University Press.

Beeby Lonsdale, A. 2000. "Choosing a Research Model for Investigating Translation Competence". In Intercultural Faultlines: Research Models in Translation Studies I: Textual and Cognitive Aspects, M. Olohan. (ed.), 43 -56. Manchester: St. Jerome Publishing.

Beeby Lonsdale, A. 1996. Teaching Translation from Spanish to English, Didactics of Translation Ser. 2, University of Ottawa Press.

Bell, R.T. 1991. Translation and Translating, London: Longman.

Campbell, S. 1998. Translation into the Second Language, London: Longman.

Canale, M. 1983. "From communicative competence to communicative language pedagogy". In Language and Communication. J.C. Richards and R.W. Schmidt (eds.), 2-27. London: Longman..

Canale, M, and Swain, M. 1980. "Theoretical Bases of Communicative Approaches to Second Language Teaching and Testing". Applied Linguistics 1(1): 1-47.

Chesterman, A. 1997. Memes of Translation. Amsterdam: John Benjamins. 
Dancette, J. 1997. "Mapping Meaning and Comprehension in Translation: Theoretical and Experimental Issues". In Cognitive Processes in Translation and Interpreting [Applied Psychology, Vol. 3.], J. Danks et al. (eds.), 77-103. Thousand Oaks: Sage Publications.

Dancette, J. 1995. Parcours de traduction: Étude expérimentale du processus de comprensión. Presses Universitaires de Lille.

Dancette, J. 1994. "Comprehension in the Translation Process: an analysis of Think-Aloud Protocols". In Teaching Translation and Interpreting 2, C. Dollerup and A. Lindegaard (eds.), 113-120. Amsterdam: John Benjamins.

Dreyfus, H.L, and Dreyfus, S.E. 1986. Mind over Machine. The Power of Human Intuition and Expertise in the Era of the Computer. Oxford: Blackwell.

Ellis, R. 1997. Second Language Acquisition, Oxford University Press.

Hansen, G. 1997. "Success in Translation", Perspectives: Studies in Translatology 5(2): 201-210.

Hansen, G. et al. 1998. "The translation process: from source text to target text”. G. Hansen. (ed.). Copenhagen Working Papers in LSP 1, 59-71.

Harris, B, and B. Sherwood. 1978. "Translating as an Innate Skill" In Language, Interpretation and Communication. D. Gerver and W. Sinaiko (eds.), 155-170. Oxford: Plenum Press.

Harris, B. "How a Three-Year-Old Translates", Patterns of Bilingualism. National University of Singapore Press, 1980. 370-393.

Harris, B. 1977. "The importance of natural translation". Working Papers on Bilingualism 12: 96-114.

Harris, B. 1973. "La traductologie, la traduction naturelle, la traduction automatique et la sémantique". Cahiers de linguistique 3: 133-146.

Hatim, B. and Mason. 1997. The Translator as Communicator, London: Routledge.

Hewson, L, and Martín, J. 1991. Redefining Translation. The variational approach. London: Routledge.

Hurtado Albir, A. 2001. Traducción y Traductología. Introducción a la Traductología. Madrid: Cátedra.

Hurtado Albir, A. 1999. "La competencia traductora y su adquisición. Un modelo holístico y dinámico". Perspectives: Studies in Translatology 7(2): 177-188.

Hurtado Albir, A. 1996a. "La cuestión del método traductor. Método, estrategia y técnica de traducción”. Sendebar. 7: 39-57.

Hurtado Albir, A. 1996b. "La enseñanza de la traducción directa 'general'. Objetivos de aprendizaje y metodología". In La enseñanza de la traducción. A. Hurtado Albir (ed.). Estudis sobre la traducció. Ser.3. Castellón: Universitat Jaume I, 31-55.

Hymes, D.H. 1971. On Comunicative Competence, Filadelfia: University of Pennsylvania Press. 
Jääskeläinen, R. 1989. “Translation Assignment in Professional Versus Nonprofessional Translation: a think-aloud protocol study". In The Translation Process, C. Seguinot (ed), 87-98. Toronto: H.G. Publications, York University.

Jääskeläinen, R. 1987. What happens in a Translation Process: think-aloud protocols of translation. Pro gradu thesis, Savonlinna School of Translation Studies: University of Joensuu.

Jääskeläinen, R., and Tirkkonen-Condit, S. 1991. "Automatised Processes in Professional vs. Non-professional Translation: a think-aloud protocol study". In Empirical Research in Translation and Intercultural Studies, S. Tirkkonen-Condit, S. (ed.), 89-109. Tübingen: Gunter Narr.

Kelly, D. A. 2002. "Un modelo de competencia traductora: bases para el diseño curricular". Puentes. Hacia nuevas investigaciones en la mediación intercultural 1.9-20.

Kiraly, D. 1995. Pathways to Translation. Pedagogy and Process, The Kent State. University Press.

Krings, H.P. 1986. Was in den Köpfen von Übersetzern vorgeht. Eine empirische Untersuchung der Struktur des übersetzungsprozesses an fortgeschrittenern. Tübingen: Gunter Narr.

Kussmaul, P. 1997. "Comprehension Processes and Translation: A Thinkaloud Protocol Study". In Translation as Intercultural Communication, Snell-Hornby, M.; Jetmarova, Z.; Kaindl, K (ed), 239-248. Amsterdam: John Benjamins.

Kussmaul, P. 1995. Training the Translator. Amsterdam: John Benjamins.

Kussmaul, P. 1991. "Creativity in the Translation Process: Empirical Approaches". K.van Leuven-Zwart and T. Naaijkens (eds.). 91-101.

Lesgold, A, and R. Glaser. 1989. Foundations for a Psychology for Education, Hillsdale: Lawrence Erlbaum Association.

Livbjerg, I, and Mees, I.M. 1999. "A study of the use of dictionaries in Danish-English translation". In Probing the process in translation: methods and results. [Copenhagen Studies in Language Series 24], G. Hansen (ed.), 135-150. Copenhagen: Samfundslitteratur.

Lorenzo, M. P. 1999. "La seguridad del traductor profesional en la traducción a una lengua extranjera". In Probing the process in translation: methods and results. [Copenhagen Studies in Language Series 24], G. Hansen (ed.), Copenhaguen: Samfundslitteratur.

Lörscher, W. 1993. "Translation Process Analysis". In SSOTT IV Translation and Knowledge. Y. Gambier and J. Tommola (eds), 195-212. Finland: University of Turku.

Lörscher, W. 1992. "Investigating the Translation Process", Méta. 37(3): 426-39.

Lörscher, W. 1991. Translation Performance, Translation Process, and Translation Strategies. A Psycholinguistic Investigation, Tübingen: Gunter Narr. 
Lowe, P. 1987. "Revising the ACTFL/ETS Scales for a New Purpose: Rating Skill in Translating". In Translation Excellence: Assessment, Achievement, Maintenance. [American Translators Association Series, Vol. 1. ], Rose, M.G. (ed.), 53-61. New York: Suny Binghamton Press.

Mondhal, M, and Jensen, K. A. 1992. "Information Processing in a Translation Task", Multilingua. 11/(2): 195-216.

Neubert, A. 2000. "Competence in Language, in Languages, and in Translation”. In Developing Translation Competence, C. Schäffner and B. Adabs (eds.), 3-18. Amsterdam: John Benjamins.

Neunzig, W. 2001. La intervención pedagógica en la enseñanza de la traducción on - line. Cuestiones de método y estudio empírico. $\mathrm{PhD}$ Thesis. Bellatera (Barcelona): Universitat Autònoma de Barcelona.

Nord, C. 1997. Translating as a Purposeful Activity. Functionalist Approaches Explained. Manchester: St. Jerome Publishing.

Nord, C. 1992. "Text analysis in translator training". In Teaching Translation and Interpreting 1, C. Dollerup and A. Lindegaard. (eds.), 39-48. Amsterdam: John Benjamins.

Orozco, M. 2001. "Revisión de investigaciones empíricas en traducción escrita", Trans 6: 63-85.

Orozco, M. 2000. Instrumentos de medida de la adquisición de la competencia traductora: Construcción y validación. $\mathrm{PhD}$ Thesis. Bellaterra (Barcelona): Universitat Autònoma de Barcelona.

PACTE. 2003. "Exploratory tests in a Study of Translation Competence". Conference Interpretation and Translation 5, (awaiting publication)

PACTE. 2002. "Una investigación empírico-experimental sobre la adquisición de la competencia traductora". In La traducción científicotécnica y la terminología en la sociedad de la información. [Estudis sobre la Traducció. Ser 10.] A. Alcina Caudet and S. Gamero Pérez (eds.), 125-138. Castellón: Universitat Jaume I.

PACTE. 2001. "La competencia traductora y su adquisición". Quaderns. Revista de Traducció 6: 39-45.

PACTE. 2000. "Acquiring Translation Competence: Hypotheses and Methodological Problems in a Research Project". In Investigating Translation, A. Beeby, D. Ensinger and M. Presas. (eds), 99-106. Amsterdam: John Benjamins.

PACTE. 1998. "La competencia traductora y su aprendizaje: Objetivos, hipótesis y metodología de un proyecto de investigación". Poster, IV Congrés Internacional sobre Traducció. Bellatera (Barcelona): Universitat Autònoma de Barcelona.

Pozo, J.I. 1996. Aprendices y maestros. Madrid: Alianza.

Pozo, J.I., and Postigo, Y. 1993. "Las estrategias de aprendizaje como contenido del currículo". In Estrategias de aprendizaje. Monereo, C. (ed.), 106-112. Barcelona: Doménech, 
Presas, M. 1996. Problemes de traducció i competència traductora. Bases per a una pedagogia de la traducció. PhD Thesis. Bellaterra (Barcelona): Universitat Autònoma de Barcelona.

Puente Ferreras, A. 1998. Cognición y aprendizaje. Fundamentos psicológicos, Madrid: Pirámide.

Pym, A. 1992. "Translation error analysis and the interface with language teaching". In Teaching Translation and Interpreting, C. Dollerup and A. Loddegaard (eds.) Amsterdam: John Benjamins.

Risku, H. 1998. Translatorische Kompetenz. Kognitive Grundlagen des Übersetzens als Expertentätigkeit, Tübingen: Stauffenburg.

Ryle, G. 1949. The concept of mind. New York: Penguin Books.

Seguinot, C. 1991. "A Study of Student Translation Strategies”. In Empirical Research in Translation and Intercultural Studies, S. Tirkonnen-Condit (ed.). Tübingen: Gunter Narr.

Shreve, M.G. 1997. "Cognition and the Evolution of Translation Competence". In Cognitive Processes in Translation and Interpreting, J.H. Danks et al. (eds.), Thousand Oaks: Sage.

Spolsky, B. 1989. "Communicative competence, language proficiency, and beyond". Applied Linguistics 10(2): 138-156.

Stanfield, C.W, Scott, M.L, and Kenyon, D.M 1992. "The Measurement of Translation Ability", The Modern Language Journal 76/(4): 455-467.

Tirkkonen-Condit, S. 1992. "The Interaction of World Knowledge and Linguistic Knowledge in the Processes of Translation: a think-aloud protocol study". In Translation and Meaning, B. LewandowskaTomaszczyk and M. Thelen (eds), Part 2, 433-440. Maastricht: Euroterm.

Tirkkonen-Condit, S. 1990. "Professional vs. Non-Professional Translation: A Think-aloud Protocol Study". In Learning, Keeping and Using Language, M.A.K.Halliday, J. Gibbons and H. Nicholas (eds.), 381-394. Amsterdam: John Benjamins.

Tirkkonen-Condit, S, and J. Lukkanen. 1996. "Evaluations: a key towards understanding the affective dimension of translational decisions". Meta. 41(1): 45-59.

Toury, G. 1995. Descriptive Translation Studies - and beyond. Amsterdam: John Benjamins.

Widdowson, H.G. "Knowledge of Language and Ability for use", Applied Linguistics 10, 2. 1989. 128-137.

Wilss, W. Kognition und Übersetzen: $\mathrm{Zu}$ Theorie und Praxis der menschlichen und der maschinellen Übersetzung. Tübingen: Niemeyer, 1988.

---. Knowledge and Skills in Translator Behavior. Amsterdam: John Benjamins, 1996. 
